\section{JCL}

Journal of the College of Languages

Open Free Access, Peer Reviewed Research Journal http://icolang.uobaghdad.edu.iq
P-ISSN: 2074-9279

E-ISSN: 2520-3517 2019, No.(39)

Pg.180-191

\title{
The Outcomes of War: A Study of the Character After the Crisis of War
}

Asst. Inst. Zainab Sameer Shakir (MA) Email: zainab_samir2004@yahoo.com Al Mamoon University College, Department of English Language.

(Received on 8/4/2018: Accepted on 3/5/2018)

\begin{abstract}
World War II has brought suffering for all people; it has led people to have a nostalgic feeling. The war has many faces all of them are ugly, like death, separation, loneliness, violence, crime, betrayal, and disconnection and many other meanings. Michael Ondaatje in his novel The English Patient (1992) portrays a picture of the effect of World War II on four different characters; Hana a Canadian nurse, The English patient who is Hungarian, Caravaggio a Canadian-Italitan thief, and Kip an Indian sapper. They live together in one house, share their secrets and memories about World War II. Ondaatje brings them together to reveal their secrets and to heal their wounds of the war experience.
\end{abstract}

Key words: War, Michael Ondaatje, The English Patient, Warfare, Healing. 
Michael Ondaatje was born in Srilanka (Ceylon) in 1943, and moved to England in 1954, then to Canada in 1962 to become a Canadian citizen. "Ceylon ... gave birth to Ondaatje, but England groomed him. He realizes that the shift offered him a different view of things, one that would give him a special opportunity... he chose to immigrate to Canada because it offered the best hope." "He spent his school years in England, and then he received a BA from the University of Toronto, and an MA from Queen's university to teach English and Canadian Literature at York University and Glendon College. ${ }^{2}$

Ondaatje's life has corresponded with an important era of history, which is marked by the end of World War II in (1945), and followed by some critical events like the foundation of United Nation in (1945), the US atomic bombs on Hiroshima and Nagasaki also in (1945), the assassination of Gandhi in (1948) and the establishment of Israel in (1948), as well as many other events that have changed the whole world. On reading Ondaatji's works, one can clearly see the effect of these events and can also feel a sense of condemn toward them.

Ondaatje started his literary career as a poet publishing 13 books of poetry, then turned to fiction, he wrote many novels like, Elimination Dance(1978),Running in the Family(1983), The Brick Reader (1991), The English Patient(1992), and many other works. The English Patient won the Booker Prize on its publication, and is adapted to movie of the same title which had The Academy Award in 1994.

The English Patient takes place toward the end of World War II. It explores the impact of the war on the lives of four survivors. Hana is a Canadian nurse, The English patient (Almasy) is a Hungarian spy, and Caravaggio is a Canadian- Italian thief and Kip who is an Indian sapper. They go in flashbacks to lead us to follow what happens to them. In a deserted 
Italian villa, once an army hospital, Hana who is a young nurse continues to give aid to her final patient, Almasy. He is a man who does not remember who he is; his plane has crashed in the Libyan Desert, "someone who looked like a burned animal" ${ }^{3}$ he is completely burned all over his body. Hana knows that he is going to die but she tries to give him as much comfort as possible. To the villa comes a thief from Toronto and a young Sikh soldier in the British Army, a sapper whose business is to defuse bombs. The lives and experience of these four persons are going to intertwine to reach a final interpretation. They reveal their past secrets and wounds of war to each other in an attempt to save their future and heal their wounds. Through this revelation the author shows the effect of the war on them.

In The English Patient, Ondaatje shows all the ugly faces of war, war comes to mean: destruction, isolation, violence, disconnection, death, crime and remoteness. The setting of the novel clearly shows these meanings as it shifts from an Italian villa after the Second World War, to the Egyptian desert pre-war. The remote and ruined Italian villa (which is used as a hospital in the time of war) is an example of the healing process after war. Although everything in the villa has been destroyed, yet Hana insists on staying in it to take care of her patient. She cleans the place up, she plants a garden, she cleans the rooms, and Kip sweeps the place free of mines. They rebuild and restore, which is something the whole world must do after the war. ${ }^{4}$

As to the second setting of the novel, when the English patient describes moments from the War, the novel goes back to the Egyptian desert in the 1930s up to just the beginning of World War II which was 1940. The desert serves as a background which puts the character against the forces of nature (heat and luck of water); it is a lifeless place so the challenge of characters in it: is to exist. Therefore, the setting has enabled the reader to clearly 
understand the evident surrounding and to construct appropriate images. ${ }^{5}$ So the villa and the desert represent the destructive, isolated, and the violent faces of war, as well as representing the image of death.

The Canadian nurse Hana is the first to introduce her war experience to us. During warfare many women entered the work force to fill the place left by men who are in the battlefield, therefore women's view on working have changed forever. Hana who is "twenty years old and mad and unconcerned with safety during this time, having no qualms about the dangers of the possibly mined" villa. (p. 13) She decides to stay in this place with her English patient because he reminds her of her father who died alone in the war. She goes through the distressing loss of her father; she could not help him or be near him while dying. So she tries to conciliate with her past, by taking care of this dying patient. She grows up quickly, cutting off her hair, just because it gets in the way of her work. War plays the main role in turning Hana's life into a black life. She sees death every day with the dying soldiers; she has lost her father, and her lover (the father of her unborn child, who was a soldier that died near her) she has also lost her girlfriend a nurse who died while working. Although war deprives Hana of her loved ones, she keeps on living; she continues to give without thinking of a thing to take. "She was living like a vagrant, while elsewhere the English patient reposed in his bed like a king." (p.14) Thus, Hana has changed from being a child into an adult. Now she takes the role of a mother taking care of her child "she would care only for the burned patient. She would read to him and bathe him and give him his doses of morphine - her only communication was with him."(p.14) Hana presents the experiences of the mother who suffer during wartime taking care of her family and cautious about her loved ones who participate in war, and might get hurt or die. Hana endures the atrocities that the nurses 
have to face when caring of wounded soldiers. Furthermore, she represents the quick change of a character from young to adult.

Ondaatje uses the character of Hana to show redemption through acceptance: Hana's character development is one from debilitating grief and denial, to healing and acceptance. Throughout the novel she refuses to acknowledge the death of her father, even going so far as to tell the patient that he is alive in France. ${ }^{6}$ Yet deep inside herself, she accepts his death and believes that she should go on with her life. By taking care of the English patient, Hana believes that she is saving herself from sadness.

The English patient chooses to hold this name (which is based on his English accent) because he is unable to recall anything even his own name. Under the effect of the morphine, he starts to have images, and reveals his past, by telling his story about who he is and how he ends burned falling from a plane on fire. The English patient is in fact László de Almásy, a Hungarian Count and desert explorer, one of many members of a British cartography group. The war has erased his identity, he becomes nameless, faceless, and nationless, and has obscured memories. He tells Hana about his love affair with Katherine Clifton the wife of his friend Geoffery Clifton who accompanied him is his desert exploration. As he knows about the affair, Geoffery plans a murder-suicide on a plane trip and crashed the plane killing himself, wounding his wife to death and ironically leaving Almasy injuryfree. Almasy tries to save Katherine; he takes her to the Cave of Swimmers and leaves her to get help but she dies there. Sometime later, Almásy retrieves Katharine's body from the Cave and, while flying back, the plane leaks oil onto him and it catches fire. He parachutes from the plane and is found by the Bedouin, truly burned. ${ }^{7}$ 
War pushes people toward having an identity with no family and nation. The war erases thenationality;Almasy feels that "gradually we became nationless. I came to hate nations...I want to erase my name and the place I had come from. By the time war arrived."(pp.138-139) In a sense, the novel is "the self portrait of Michael Ondaatje; it contains his archetype of self and his bewilderment about his own uncertain origin- Srilanka, England, Canada." 8

Almasydislikes nations because a friend of him kills himself for he cannot stand war, and the loss of civilization. Presenting this type of character, Ondaatje wants to show how war plays a role in making people lose their nationality being spies or working for the other part of the war, or even travel away from their nations to escape the violence of war. The war works at erasing nationality, like the sand of the desert; and like the remoteness of the villa: where identity is not important. Sometimes in times of war identity is defined as nationality. The English language of Almasymarks his identity as an English person, but he can also speak many other languages like Greek, German, Arabian Accent as well as Hungarian: in this way he could have different identities. Ironically, at the end when his real nationality is revealed, not English but Hungarian. War does not only erase his identity but also turns him into a person with unrecognizable face, body, race and origin even his color has changed from white to black. So it erases his physical features forever, he does not look like Almasy, but as someone else having no past.

Hana and her patient are joined by Caravaggio, a Canadian- Italian thief, who works as a spy in the British foreign intelligence service since the late 1930s; Caravaggio is a friend of Hana's father. He is a thief turned into a spy because of the warfare. He is eventually caught by the Germans and interrogated, and tortured; they even cut off his thumbs, he has given his thief's hand to the mission. For Caravaggio war means, violence and crime, 
he bears physical and psychological scars from his painful war experience for which he seeks vengeance.

In his book Michael Ondaatje, Douglas Barbour states: "Both Hana and Caravaggio have been changed by the war. And the two new characters with whom their lives intertwine provide further changes, beyond measurement but not beyond figuration." 9

As a product of the war, Caravaggio becomes violent, he does not think of the English patient as a human being but as an enemy. When he suspects the English patient is the Hungarian spy, Almasy, Caravaggio mercilessly injects the patient with more morphine only to question him about his identity. Thus, as a result of war, Caravaggio has been changed (physically and emotionally) forever (cutting his thumb) causes him to be a merciless person. He hates Almasy and tries to kill him.

Caravaggio used to be a gregarious and confident man, but the war and torture have broken his spirit. He is a personification of the futility of war. As well as being the most vocal about his disdain for the war and its waste, his maimed hands are both evidence and symbols of its futility. ${ }^{10}$

Two British soldiers come to the villa to deactivate the bombs that the Germans trapped in. One of the soldiers, Kirpal Singh, named Kip by the English he has worked with. Kip is a self-sufficient man, comes from a colonized country.He is an emissary of the British and highly influenced by their culture (the colonizer), even greatly admires it. Kip is an Indian Sikh who looks at the West, he likes the English tea but adds his own condensed milk to it, wears his turban but their uniform. This type of character is a product of war, he is created by wars in a way that people especially young, are affected by the other part of war, at the same time they want to keep their 
own traditions so the result is a hybrid character.Hybridity commonly refers to the new transcultural forms created by the colonization. The hybrid character emerges with contradiction and ambivalence, lives in an in-between space that carries the meaning of two cultures.

At the beginning Kip is a sapper who defuses bombs for the English after World War II, but at the end of the novel, he is a doctorwho lives peacefully in India with his Indian wife and children.

Kip represents isolation. His outward look, his cultural background and his dark brown skin are clearly recognized. While staying at the villa to attempt to clear it of unexploded ordnance,Kip falls in love with Hana who has the same feelings toward him. He also becomesa friend with the English patient as he used to celebrate the English people. But then he gets into a trauma as a result of what he has seen in war. The violence of war turns Kip into a skeptical isolated person. "Ah, but my brother thinks me a fool for trusting the English... how we throw ourselves into English wars.”(p. 217) Through Kip's character, Ondaatje tries to give an example of how war deprives a person of an important aspect of life: that is (trust). Instead of faith and trust, suspension becomes the ground of Kip's being. ${ }^{11}$ As soon as he hears the savage news of the Western attack on Japanese civilians, he is shocked. He realizes the falsehood of the images he had held up so high. He takes his gun and tries to shoot the English patient. Singh states that: "this aggressive act is a meaningful response, revealing Kip's new found ego."

Ondaatje creates a complex love relationship between Kip and Hana. Hana turns to the east to find peace, and Kip turns to the west thinking that it is the best.Their relationship crosses culture boundaries, but ends as soon as Kip hears the news of the American Atomic bomb on Hiroshima and Nagasaki in1945. Now Kip's belief in the west has been shattered. He refuses to be Kip 
anymore; he isKirpal again, stating that they "never would have dropped such a bomb on a white nation" (p.286) So Kip is presented as a victim of the machines of the war that numb his mind and heart. The relationship between Kip and Hana is based on mutual needs. He needs Hana as a mother or sister, as well as a lover. While he understands Hana'sreasons of sorrow: "Heknows the depth of darkness in her, her lack of a child and of faith. Heis always coaxing her from the edge of her fields of sadness."13 Accordingly, both Kipand Hana think that they are being needed by each other, as Ondaatje says about all thecharacters in the novel: "I think everyone thinks they're healing everybody else, in some way,but they're all wounded". ${ }^{14}$

The English patient is a novel with an international concept, it marks a time of great changes in the world, and its main concern is on how war affects human beings and how they react toward it. Hana plays the role every womanplay in wartime; to her the war means loneliness and death, for she has lost her dear ones. War also means separation to her because she and Kip are separated because of war. Yet Hana grows more mature by gaining more power and confidence. She creates a family atmosphere in a place smells like death. In some way the effect of war is seen positive upon Hana for it shows her true powerful and thoughtful character. Kip is changed by the war, from a person who idealizes the west, to someone who realizes the injustice of war. He realizes the significance of the Indian traditions, which he used to disgrace before. The English patient is a victim of war; who has lost everything even his own senses as he is burned from head to toe. The War has also changed Caravaggio forever cutting off his thumbs, he turns from a thief stealing the properties of people into a spy who steals and creates identities. Then he degrades into a vile person. 


\section{Notes}

1 E D Jewinski, Michael Ondaatje: Express Yourself Beautifully (Toronto: ECW Press, 1994), p. 23-24

2 "Michael Ondaatje" From Wikipedia, the free encyclopedia https://en.wikipedia.org/wiki/Michael_Ondaatje 31/3/2018

3 Michael Ondaatje, The English Patient (New York: Vintage International, 1993), p.207

Henceforward, all references to the novel will be to this edition, therefore only page number(s) are parenthetically cited within the text.

4 "The English Patient" (1996) Directed by Anthony

Minghellahttp://www.shmoop.com/the-english-patient/setting.html

$\underline{31 / 3 / 2017}$

5 "Importance of Setting in The English Patient" http://englishpatientblockb.blogspot.com/2013/02/importance-ofsetting-in-english-patinet.html 31/3/2017

${ }^{6}$ Sara Constantakised, A Study Guide for Michael Ondaatje's "The English Patient," USA: Gale Publication, 2006. Kindle Edition.

7 "The English Patient" From Wikipedia, the free encyclopedia https://en.wikipedia.org/wiki/The_English_Patient\#Plot_synopsis 31/3 12017

${ }^{8}$ E D Jewinski, p. 132.

9 Douglas Barbour, Michael Ondaatje (NY: Twayne Publishers, 1993), p. 208.

${ }^{10}$ Sara Constantakis.

11 Arvind-Pal S. Mandair, et al. Sikh Religion, Culture and Ethnicity (London: Routledge, Taylor and Francis, 2013), p.125.

12 Ibid. p. 134.

${ }^{13}$ Douglas Barbour, p. 271. 
${ }^{14}$ Johanna Tapio, “The Sacredness of Bridges: Kip's Role as Mediator in Michael Ondaatje's The English Patient" Thesis, University of Tampere, 2007. Web 23 March 2018.

\section{References}

1. Barbour, Douglas. Michael Ondaatje NY: Twayne Publishers, 1993

2. Constantakis, Sara ed. A Study Guide for Michael Ondaatje's "The English Patient," USA: Gale Publication, 2006.

3. "Importance of Setting in The English Patient" http://englishpatientblockb.blogspot.com/2013/02/importance-ofsetting-in-english-patinet.html

4. Jewinski, E D. Michael Ondaatje: Express Yourself Beautifully. Toronto: ECW Press, 1994.

5. Mandair, Arvind-Pal S. et al. Sikh Religion, Culture and Ethnicity. London: Routledge, Taylor and Francis, 2013

6. "Michael Ondaatje" From Wikipedia, the free encyclopedia https://en.wikipedia.org/wiki/Michael_Ondaatje

7.Ondaatje, Michael. The English Patient.New York: Vintage

8. International, 1993.

9. Tapio, Johanna “The Sacredness of Bridges: Kip's Role as Mediator in Michael Ondaatje's The English Patient" Thesis, University of Tampere, 2007.

10. "The English Patient" (1996) Directed by Anthony Minghellahttp://www.shmoop.com/the-english-patient/setting.html

11. "The English Patient" From Wikipedia, the free encyclopedia https://en.wikipedia.org/wiki/The_English_Patient\#Plot_synopsis 


\section{مخرجات الحرب: دراسة الشخصية بعد ازمة الحرب}

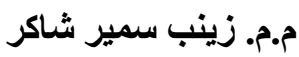

كلية المأمون الجامعة / قسم اللغة الانكليزية

\section{خلاصة البحث}

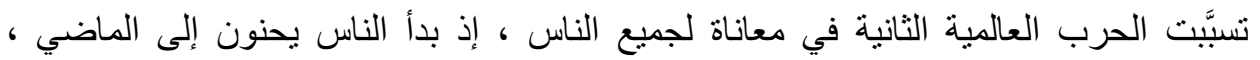
فللحرب وجوه كثيرة ، جميعها بشعة ، مثل الموت ، و الفراق ، و الثعور بالوحدة ، و العنف ، و الجريمة ، والخيانة ، والانفصال، وكثير من المعاني الأخرى. يقدم الكاتب مايكل اونداتجي في روايته (المريض الانكليزي 1992) صورة عن اثر الحرب العالمية الثانية في اربع شخصيات ، هم :حانا الممرضة الكندية ، و المانشي و هو المريض الانكليزي من أصل مجري ، و كار افاجيو اللص الايطالي من اصل كندي، وكيب مفكك الالغام من أصل هندي. يعيش هؤلاء الأربعة معا في منزل واحد ، يتبادلون أسرارهم وذكرياتهم عن الحرب العالمية الثانية. يقوم أونداتجي بجمعهم معًا ليكثف عن لهن أسر ار هم في محاولة لتضميد جروحهم من تجربة الحرب. الكلمات المفتاحية: الحرب , مايكل اونداتجي , المريض الانكليزي , الحرب , الثفاء

\section{About the author}

Assis. Instructor: Zainab Sameer Shakir MA degree

Educated from: College of Arts/ University of Baghdad Department of English Language

Place of work: Department of English Language

Al Mamoon University College

zainab_samir2004@yahoo.com

Email: zainab_samir2004@yahoo.com 